University of Wollongong

Research Online

Faculty of Social Sciences - Papers (Archive) Faculty of Arts, Social Sciences \& Humanities

2015

Qualitative research with families living with autism spectrum disorder: Recommendations for conducting semistructured interviews

\author{
Elizabeth Kate Cridland \\ University of Wollongong, ekc977@uowmail.edu.au \\ Sandra C. Jones \\ University of Wollongong, sandraj@uow.edu.au \\ Peter Caputi \\ University of Wollongong, pcaputi@uow.edu.au \\ Christopher Magee \\ University of Wollongong, cmagee@uow.edu.au
}

Follow this and additional works at: https://ro.uow.edu.au/sspapers

Part of the Education Commons, and the Social and Behavioral Sciences Commons

Research Online is the open access institutional repository for the University of Wollongong. For further information contact the UOW Library: research-pubs@uow.edu.au 


\title{
Qualitative research with families living with autism spectrum disorder: Recommendations for conducting semistructured interviews
}

\author{
Abstract \\ In this paper, the insights and experiences of a research team involved in conducting qualitative research \\ with families living with autism spectrum disorder are drawn upon to provide reflections and \\ recommendations across all stages of the qualitative research process. Particular attention is given to \\ the steps involved in semistructured interviews, specifically, interview guide preparation, participant \\ recruitment, obtaining informed and voluntary consent/assent, conducting effective interviews, accurate \\ analysis and interpretation of data, ways to involve participants in data analysis, effective communication \\ of research findings, and providing feedback to participants. In addition, reflections and \\ recommendations are provided for maintaining researcher health throughout the qualitative research \\ process.

\section{Keywords} \\ autism spectrum disorder, qualitative, family systems, research methodology, semistructured interviews, \\ self-care

\section{Disciplines} \\ Education | Social and Behavioral Sciences

\section{Publication Details} \\ Cridland, E. K., Jones, S. C., Caputi, P. \& Magee, C. A. (2015). Qualitative research with families living with \\ autism spectrum disorder: Recommendations for conducting semistructured interviews. Journal of \\ Intellectual and Developmental Disability, 40 (1), 78-91.
}


CONCEPTUAL PAPER

Qualitative research with families living with autism spectrum disorder: Recommendations for conducting semistructured interviews

\section{ELIZABETH K. CRIDLAND ${ }^{1,2}$, SANDRA C. JONES $^{2,3}$, PETER CAPUTI ${ }^{1,2}$ \& CHRISTOPHER A. MAGEE ${ }^{2}$}

${ }^{1}$ School of Psychology, University of Wollongong, Wollongong, Australia, ${ }^{2}$ Centre for Health Initiatives, University of Wollongong, Australia, and ${ }^{3}$ Centre for Health and Social Research, Australian Catholic University, Melbourne, Australia

Correspondence: Elizabeth K. Cridland, School of Psychology, Building 41, University of Wollongong, Wollongong NSW, 2522, Australia.E-mail: ekc977@uowmail.edu.au

Keywords: autism spectrum disorder, qualitative, family systems, research methodology, semistructured interviews, self-care 


\begin{abstract}
In this paper, the insights and experiences of a research team involved in conducting qualitative research with families living with autism spectrum disorder are drawn upon to provide reflections and recommendations across all stages of the qualitative research process. Particular attention is given to the steps involved in semistructured interviews, specifically, interview guide preparation, participant recruitment, obtaining informed and voluntary consent/assent, conducting effective interviews, accurate analysis and interpretation of data, ways to involve participants in data analysis, effective communication of research findings, and providing feedback to participants. In addition, reflections and recommendations are provided for maintaining researcher health throughout the qualitative research process.
\end{abstract}




\section{Introduction}

Research focusing on the experiences of individuals with autism spectrum disorder (ASD) and their families is on the rise (Bayat, 2007; Bradford, 2010; Hastings \& Taunt, 2002). Reasons for this growing research attention include the increase in individuals being diagnosed with ASD (Boelte \& Poustka, 2000; Duchan \& Patel, 2012; Fombonne, 2002, 2003), and a growing recognition of the importance of understanding the complex impact ASD has on families (Cridland, Jones, Magee, \& Caputi, 2014; Morgan, 1988; Seligman \& Darling, 2007). Many of the studies in this area have used qualitative methodologies (Cocks, 2008; Mascha \& Boucher, 2006). The benefits of using qualitative approaches when investigating families living with ASD include their capacity to measure complex issues (such as family dynamics and mixed or ambiguous attitudes; Cridland, Jones, et al., 2014; Dew, Balandin, \& Llewellyn, 2008; King et al., 2006; Meadan, Stoner, \& Angell, 2010) and emphasis on presenting rich descriptions rather than on testing a priori hypotheses (Krogh \& Lindsay, 1999). In addition, qualitative approaches are considered an appropriate method when involving children (Dockett, Einarsdottir, \& Perry, 2009; Mishna, Antle, \& Regehr, 2004) and individuals with disability (Barnes, 1992; Cocks, 2008) in research.

Of the range of qualitative methods (e.g., unstructured interviews, focus groups, observations, diaries, etc.), semistructured interviews are one of the most commonly used in this research area (Krogh, \& Lindsay, 1999). Semistructured interviews involve in-depth conversations between the researcher and interviewee, which have an overall purpose prompted by the research aims, but are strongly guided by the interviewee's perceptions, opinions, and experiences (Carrington \& Graham, 2001; Minichiello, Aroni, Timewell, \& Alexander, 1995). The benefits of using semistructured interviews with families living with ASD include flexibility to focus on issues that are meaningful to participants (Barbour, 2000), permitting diversity of perceptions rather than being inhibited by "standard" or 
“expected” response categories (Mascha \& Boucher, 2006; Petalas, Hastings, Nash, Dowey, \& Reilly, 2009), and minimisation of researcher control over participants' expression of their experiences (Brewin, Renwick, \& Fudge Schormans, 2008).

Literature exists for conducting qualitative research with children (Docket et al., 2009; Mishna et al., 2004) and individuals with learning disability (Cocks, 2008; Krogh \& Lindsay, 1999). However, despite the increase in qualitative research conducted with families living with ASD, we were unable to identify guidelines specifically for conducting research with this population. Identification of specific considerations for conducting qualitative research with individuals with ASD and their families is needed, as literature based on either neurotypically developing (NTD) children or individuals with other disabilities cannot be directly applied to individuals with ASD. Central to this are the various social and communication impairments, behavioural difficulties, and cognitive processing differences inherent in ASD (Attwood, 2007; Deruelle, Rondan, Gepner, \& Fagot, 2006; Sachse et al., 2013). There are also various unique experiences for family members of individuals with ASD that are worthy of consideration when conducting qualitative research with this population. Such unique experiences include positive and rewarding aspects of having a family member with ASD (Bayat, 2007; Pakenham et al., 2005, ongoing grief responses (O’Brien, 2007), and management of a range of unique intolerances, social misunderstandings, and sudden mood changes exhibited by their family member with ASD (Attwood, 2007; Heiman \& Berger, 2008; Macks \& Reeve, 2007). These and other experiences warrant specific considerations for conducting research with this population.

The reflections and recommendations throughout this paper cover all stages of the qualitative research process. Figure 1 depicts these stages, which include research preparation, data collection, data analysis, and dissemination of research findings. 
Consideration is also given to the health and wellbeing of researchers in this area across all stages of the research process.

\section{$<<$ PLEASE INSERT FIGURE 1 ABOUT HERE $>>$}

\section{Preparation}

Interview guide development. Preparation is an important aspect of all research (Dickson-Swift, James, Kippen, \& Liamputtong, 2007, 2008; Sandelowski, 1995). A critical component of preparation in qualitative research using semistructured interviews is the development of the interview guide (Minichiello et al., 1995). The interview guide underpins the interview process and therefore influences subsequent research stages (Minichiello et al., 1995). Given the range of considerations related to interviewing an individual with ASD (such as discomfort discussing certain topics, preferring to discuss topics of interest to them), a strong interview guide is likely to help researchers focus on these aspects rather than on practical components of the interviews (e.g., appropriate wording of interview questions).

Participant recruitment. Effective recruitment strategies are another critical component of all research studies, as recruitment of an appropriate sample is a founding element to valid research data (Minichiello et al., 1995). Traditionally, recruitment of participants has relied on flyers, posters, and information in community newsletters (Minichiello et al., 1995). However, there may be various barriers to using traditional approaches when recruiting individuals with ASD given that responding to such material requires a willingness to engage socially (usually by phone contact) with the researchers. Social discomfort inherent in such engagement may present as a barrier to some individuals with ASD signing up for the study.

There may also be barriers to using such approaches when recruiting families of individuals with ASD. First, families living with ASD may frequently receive invitations to participate in research and, given the impersonal nature of traditional recruitment approaches, 
they may be less likely to read and respond to them (Krogh \& Lindsay, 1999). Additionally, responding to a study flier is unlikely to be a priority for families living with ASD, given they are busy with the pressures of having a family member with ASD in addition to the usual stressors of family life (Heiman \& Berger, 2008; Macks \& Reeve, 2007; Pakenham, Samios, \& Sofronoff, 2005). Further, there is the possibility of recruiting a skewed sample when relying on these approaches as "high-functioning" families may be more likely to respond (Kirkland, 2012).

Obtaining informed and voluntary assent/consent. Obtaining informed and voluntary consent is a necessary component of all research (Agre \& Rapkin, 2003). It ensures that individuals understand the study aims, the commitment of being involved in the study, any potential risks and benefits of being involved, and the expected outcomes of the research (Agre \& Rapkin, 2003; van den Hoonaard, 2002). Further, informed consent is an ongoing process, rather than a time-limited event, and is best sought at all stages of research (van den Hoonaard, 2002).

Although parents/carers of individuals with ASD are likely to be the family members who initially show interest in the study, it is important to ensure they do not provide consent on behalf of other members of their family. Individuals with ASD (Cocks, 2008) and children (e.g., NTD siblings; Mishna, et al., 2004; Potter \& Hepburn, 2005) may be particularly vulnerable to having their consent provided for them (Cocks, 2008). Similarly, although parental/carer consent is generally the primary requirement needed for children to be involved in research, this should not replace obtaining assent from the individuals with ASD and children themselves (Dockett et al., 2009).

Data collection

Appropriate interview settings. In this field of research, semistructured interviews are often conducted within the family home (Mascha \& Boucher, 2006). Benefits of this 
approach include avoiding connotations of a clinical assessment, promoting familiarity for participants, and gaining a unique understanding of family dynamics (Mascha \& Boucher, 2006).

The main challenge of conducting interviews within the family home is ensuring interviews are completed in an appropriate private space to maintain participant confidentiality (Mascha \& Boucher, 2006). Participants may not recognise the importance of conducting the interviews in a private space, particularly if they indicate that their family is “open” with discussing all issues in front of each other (Dockett et al., 2009). If this is the case, it is important to discuss the need for participant confidentiality. Other possible drawbacks of conducting interviews within the family home include safety issues and practicalities of travel for researchers (Minichiello et al., 1995).

Practicalities of conducting interviews. Numerous practical issues need to be considered when conducting qualitative research with families living with ASD. Such issues include organising interviews at an appropriate time of day for participants, allowing ample time to travel to scheduled interviews, conducting interviews at an appropriate pace, and considering the most appropriate method of recording the interview (e.g., scribing, voicerecording, or video-recording). Consideration of such issues during the planning stages of research will help facilitate effective interviews. Additionally, it may be necessary to reflect on the processes in place during the data collection stages and make appropriate changes if warranted.

The skill base of interviewers is an important consideration in all qualitative research (Brinkmann, 2007). Generally it is recommended that, at a minimum, interviewers are well acquainted with the interview guide and familiar with the interview process (Brinkmann, 2007; Minichiello et al., 1995). Additionally, personality characteristics such as patience, an open and empathetic attitude, and an ability to listen are highly valued (Brinkmann, 2007). In 
the context of ASD research, it is also important that researchers have a clear understanding of the characteristics of ASD and how these may present in participants (Cocks, 2008; Krogh, \& Lindsay, 1999).

Data analysis

Accurate analysis and interpretation of data. In qualitative research, data analysis and interpretation are overlapping, yet conceptually different, processes. More specifically, qualitative analysis involves the breaking down of data, whereas qualitative interpretation illuminates a new way of understanding the data while remaining faithful to the original data (van den Hoonaard, 2002). It is important to note that the analysis and interpretation stages of qualitative research are influenced by all other stages of research, including preparation, data collection, transcribing, and reading of transcripts (van den Hoonaard, 2002).

Issues to be considered during data analysis and interpretation include considering transcribing as an integral component to the data analysis process, reflecting on what participants discuss as well as issues they do not discuss in interviews, and having multiple researchers involved in the analysis and interpretation of data.

Involving participants in data analysis. Involving participants in data analysis is a relatively recent concept (Dockett et al., 2009). The rationale behind involving participants in data analysis is to ensure data are accurate (Dockett et al., 2009) and in line with the process of ongoing informed consent (van den Hoonaard, 2002). There are benefits of including participants in data analysis, such as giving participants the opportunity to reflect on their interviews and brainstorm "themes" emerging from their interviews, and developing an appreciation of the research process (Dockett et al., 2009). Further, some participants may find such involvement to be rewarding and/or therapeutic (Dockett et al., 2009).

One challenge of involving participants in data analysis processes is the possibility that participants may reflect on certain things they had said (particularly discussion of 
negative aspects of living with ASD) and express a desire for such aspects of the interview to not be included in analysis (Barbour, 2000). Another challenge may be participants asking to read other family members' transcripts, particularly parents asking to read their children's transcripts. Strategies to manage these challenges include normalising experiences of discomfort when reading transcripts, discussing the use of deidentified data when reporting results, discussing the rights of participants to withdraw consent from the study, and discussing the rationale regarding not allowing participants to read other family members transcripts (i.e., participant confidentiality).

\section{Dissemination of findings}

Effective communication of research findings. The communication of qualitative research studies is traditionally confined to academic journal articles and/or conference proceedings (Keen \& Todres, 2007). This can often limit the application of research findings in facilitating positive change for the lives of those affected by the research-in this case families living with ASD. Put another way, the dissemination of research findings to practice is often seen as a task beyond the research process (Keen \& Todres, 2007). However, we recommend considering the dissemination of research findings as an integral component of the research process (see Figure 1).

The intended target audience of the research is the criteria on which dissemination strategies should be based. Target audiences for research focusing on individuals with ASD include families, clinicians, health practitioners, teachers, policymakers, and so on. Therefore, dissemination strategies may include a range of approaches from presenting to local ASD community groups to presenting to key stakeholders such as governments and other policymakers.

Providing feedback to participants. Communicating feedback to participants about the results of the study is not considered a necessary component of the research process. 
However, there may be a range of benefits of doing so. First, feedback provides participants with findings of the study and overall outcomes of the research (e.g., policy changes, publications, funding, etc.) that they may not otherwise have learned. Additionally, families living with ASD who participate in ASD research are likely to have a genuine interest in the research outcomes and therefore appreciate feedback. Feedback also acknowledges the significant commitment of participating in research and may facilitate participants having positive experiences of being involved in qualitative research. Further, providing feedback to participants may help consolidate research findings for the researcher and highlight the issues of importance for families living with ASD (Keen \& Todres, 2007). Feedback about research findings and outcomes may occur periodically or at the conclusion of the research, depending on the nature of the project.

\section{Researcher health}

Importance of self-care. Self-care involves a range of activities aimed at ensuring the physical, emotional, and psychological wellbeing of the researcher, such as exercise, social activities, hobbies, and travelling. The importance of self-care for qualitative researchers investigating emotionally laden topics is recognised but often overlooked (Rager, 2005a, 2005b; Stamm, 1999). Researcher self-care is imperative across all aspects of the research process.

In discussing the potential for emotional effects of conducting qualitative research with families living with ASD, it is not our intention to recommend that researchers guard against all emotional reactions to research. On the contrary, we recognise the important role of emotion in qualitative research (Brinkmann, 2007; Rager, 2005a, 2005b), such as the ability to empathetically consider the psychological world of participants. Rather, we recommend that researchers use strategies to manage the possible negative emotional effects of conducting qualitative research. Such strategies include being involved in debriefing 
sessions, maintaining a journal, and organising interviews with adequate spacing to reduce the intensity of interviewing commitments and allow ample time for reflection between interviews.

Developing and maintaining healthy boundaries. In qualitative research, it is common for researchers to negotiate multiple roles (such as data collector and empathetic listener; Lavis, 2010). In fact, these multiple roles are often considered necessary for effective qualitative research whereby the researcher must conduct ethical practices while also developing authentic relationships with participants (Lavis, 2010). Developing and maintaining healthy boundaries around researcher roles is critical for conducting research in this field, given the potential for role confusion that may result when involving children and/or individuals with disability in research (Brinkmann, 2007). Boundary confusion is a bidirectional process whereby misunderstandings from either the researchers or participants can result in inappropriate roles (Brinkmann, 2007). Strategies to help maintain healthy boundaries include a clear understanding for both researchers and participants about the role of the researcher and limitations to this role, and using various monitoring strategies such as other researchers attending the interviews or reading the transcripts.

Table 1 provides detailed recommendations based on the issues discussed. The recommendations are based on the literature and experiences from the authors' involvement in qualitative research focusing on families living with ASD.

\section{Conclusion}

Conducting qualitative research with individuals with ASD and their families is not easy, as highlighted by the range of challenges and considerations discussed throughout this manuscript. However, with these challenges also comes a multitude of rewards; predominantly, the opportunity to meet a range of different people and hear their stories. Just as we attempt to do justice to the significance of participants' experiences during the write-up 
of empirical papers, we aim to honour the significance of our research practices by sharing our experiences with other researchers with this paper. The issues discussed contribute to existing knowledge regarding conducting qualitative research with individuals with ASD and their families and promotes our understanding of ASD in general. 


\section{References}

Agre, P., \& Rapkin, B. (2003). Improving informed consent: A comparison of four consent tools. IRB: Ethics and Human Research, 25(6), 1-7. doi:10.2307/3564285

Attwood, T. (2007). The complete guide to Asperger's syndrome. London, UK: Kingsley.

Barbour, R. S. (2000). The role of qualitative research in broadening the 'evidence base' for clinical practice. Journal of Evaluation in Clinical Practice, 6, 155-163. doi:10.1046/j.1365-2753.2000.00213.x

Barnes, C. (1992). Qualitative research: Valuable or irrelevant? Disability, Handicap \& Society, 7, 115-124. doi:10.1080/02674649266780151

Bayat, M. (2007). Evidence of resilience in families of children with autism. Journal of Intellectual Disability Research, 51, 702-714. doi:10.1111/j.1365-2788.2007.00960.x

Boelte, S., \& Poustka, F. (2000). Diagnosis of autism: The connection between current and historical information. Autism, 4, 382-390. doi:10.1177/1362361300004004004

Bradford, K. (2010). Supporting families dealing with autism and Asperger's disorders. Journal of Family Psychotherapy, 21, 149-156. doi:10.1080/08975353.2010.483660

Braun, V., \& Clarke, V. (2006). Using thematic analysis in psychology. Qualitative Research in Psychology, 3, 77-101. doi:10.1191/1478088706qp063oa

Brewin, B. J., Renwick, R., \& Fudge Schormans, A. (2008). Parental perspectives of the quality of life in school environments for children with Asperger syndrome. Focus on Autism and Other Developmental Disabilities, 23, 242-252. doi:10.1177/1088357608322997

Brinkmann, S. (2007). The good qualitative researcher. Qualitative Research in Psychology, 4, 127-144. doi:10.1080/14780880701473516 
Carrington, S., \& Graham, L. (2001). Perceptions of school by two teenage boys with Asperger syndrome and their mothers: A qualitative study. Autism, 5, 37-48. doi:10.1177/1362361301005001004

Cocks, A. (2008). Researching the lives of disabled children: The process of participant observation in seeking inclusivity. Qualitative Social Work, 7, 163-180. doi:10.1177/1473325008089628

Cridland, E. K., Caputi, P., Jones, S. C., \& Magee, C. A. (2014). Understanding high functioning autism during adolescence: A personal construct theory approach. Journal of Intellectual \& Developmental Disability, 39, 108-118. doi:10.3109/13668250.2013.870331

Cridland, E. K., Jones, S. C., Magee, C. A., \& Caputi, P. (2014). Family-focused autism spectrum disorder research: A review of the utility of family systems approaches. Autism, 18, 213-222. doi:10.1177/1362361312472261

Davis, K., \& Gavidia-Payne, S. (2009). The impact of child, family, and professional support characteristics on the quality of life in families of young children with disabilities. Journal of Intellectual \& Developmental Disability, 34, 153-162. doi:10.1080/13668250902874608

Deruelle, C., Rondan, C., Gepner, B., \& Fagot, J. (2006). Processing of compound visual stimuli by children with autism and Asperger syndrome. International Journal of Psychology, 41, 97-106. doi:10.1080/00207590500184610

Dew, A., Balandin, S., \& Llewellyn, G. (2008). The psychosocial impact on siblings of people with lifelong physical disability: A review of the literature. Journal of Developmental and Physical Disabilities, 20, 485-507. doi:10.1007/s10882-008$9109-5$ 
Dickson-Swift, V., James, E. L., Kippen, S., \& Liamputtong, P. (2007). Doing sensitive research: What challenges do qualitative researchers face? Qualitative Research, 7, 327-353. doi:10.1177/1468794107078515

Dickson-Swift, V., James, E. L., Kippen, S., \& Liamputtong, P. (2008). Risk to researchers in qualitative research on sensitive topics: Issues and strategies. Qualitative Health Research, 18, 133-144. doi:10.1177/1049732307309007

Dockett, S., Einarsdottir, J., \& Perry, B. (2009). Researching with children: Ethical tensions. Journal of Early Childhood Research, 7, 283-298. doi:10.1177/1476718X09336971

Duchan, E., \& Patel, D. R. (2012). Epidemiology of autism spectrum disorders. Pediatric Clinics of North America, 59, 27-43. doi:10.1016/j.pcl.2011.10.003

Fombonne, E. (2002). Epidemiological trends in rates of autism. Molecular Psychiatry, 7(Suppl. 2), S4-S6. doi:10.1038/sj.mp.4001162

Fombonne, E. (2003). Epidemiological surveys of autism and other pervasive developmental disorders: An update. Journal of Autism and Developmental Disorders, 33, 365-382. doi:10.1023/A:1025054610557

Hastings, R. P., \& Taunt, H. M. (2002). Positive impact of children with developmental disabilities on their families: A preliminary study. Education and Training in Mental Retardation and Developmental Disabilities, 37, 410-420.

Heiman, T., \& Berger, O. (2008). Parents of children with Asperger syndrome or with learning disabilities: Family environment and social support. Research in Developmental Disabilities, 29, 289-300. doi:10.1016/j.ridd.2007.05.005

Keen, S., \& Todres, L. (2007). Strategies for disseminating qualitative research findings: Three exemplars. Forum: Qualitative Social Research, 8(3). Retrieved from http://nbn-resolving.de/urn:nbn:de:0114-fqs0703174 
King, G. A., Zwaigenbaum, L., King, S., Baxter, D., Rosenbaum, P., \& Bates, A. (2006). A qualitative investigation of changes in the belief systems of families of children with autism or Down syndrome. Child: Care, Health and Development, 32, 353-369. doi:10.1111/j.1365-2214.2006.00571.x

Kirkland, S. R. (2012). The perceived relationship between a mother and her child on the autism spectrum (Unpublished postgraduate thesis). University of Wollongong, Australia.

Krogh, K. S., \& Lindsay, P. H. (1999). Including people with disabilities in research: Implications for the field of augmentative and alternative communication. Augmentative and Alternative Communication, 15, 222-233. doi:10.1080/07434619912331278765

Lavis, V. (2010). Multiple researcher identities: Highlighting tensions and implications for ethical practice in qualitative interviewing. Qualitative Research in Psychology, 7, 316-331. doi:10.1080/14780880902929506

Macks, R. J., \& Reeve, R. E. (2007). The adjustment of non-disabled siblings of children with autism. Journal of Autism and Developmental Disorders, 37, 1060-1067. doi:10.1007/s10803-006-0249-0

Mascha, K., \& Boucher, J. (2006). Preliminary investigation of a qualitative method of examining siblings' experiences of living with a child with ASD. British Journal of Developmental Disabilities, 52(102), 19-28. doi:10.1179/096979506799103659

Meadan, H., Stoner, J. B., \& Angell, M. E. (2010). Review of literature related to social, emotional and behavioral adjustment of siblings with autism spectrum disorder. Journal of Developmental and Physical Disabilities, 22, 83-100. doi:10.1007/s10882009-9171-7 
Meirsschaut, M., Roeyers, H., \& Warreyn, P. (2011). The social interactive behaviour of young children with autism spectrum disorder and their mothers: Is there an effect of familiarity of the interaction partner? Autism, 15, 43-64. doi:10.1177/1362361309353911

Minichiello, V., Aroni, R., Timewell, E., \& Alexander, L. (1995). In-depth interviewing: Principles, techniques, analysis (2nd ed.). Sydney, Australia: Longman.

Mishna, F., Antle, B. J., \& Regehr, C. (2004). Tapping the perspectives of children: Emerging ethical issues in qualitative research. Qualitative Social Work, 3, 449-468. doi:10.1177/1473325004048025

Morgan, S. B. (1988). The autistic child and family functioning: A developmental-family systems perspective. Journal of Autism and Developmental Disorders, 18, 263-280. doi:10.1007/BF02211952

Mossman Steiner, A. (2011). A strength-based approach to parent education for children with autism. Journal of Positive Behavior Interventions, 13, 178-190. doi:10.1177/1098300710384134

Myles, B. S., \& Simpson, R. L. (1998). Asperger syndrome: A guide for educators and parents. Austin, TX: Pro-Ed.

Naber, F. B. A., Bakermans-Kranenburg, M. J., van IJzendoorn, M. H., Swinkels, S. H. N., Buitelaar, J. K., Dietz, C., ... van Engeland, H. (2008). Play behavior and attachment in toddlers with autism. Journal of Autism and Developmental Disorders, 38, 857866. doi:10.1007/s10803-007-0454-5

O’Brien, M. (2007). Ambiguous loss in families of children with autism spectrum disorders. Family Relations, 56, 135-146. doi:10.1111/j.1741-3729.2007.00447.x 
Pakenham, K. I., Samios, C., \& Sofronoff, K. (2005). Adjustment in mothers of children with Asperger syndrome: An application of the double ABCX model of family adjustment. Autism, 9, 191-212. doi:10.1177/1362361305049033

Petalas, M. A., Hastings, R. P., Nash, S., Dowey, A., \& Reilly, D. (2009). "I like that he always shows who he is": The perceptions and experiences of siblings with a brother with autism spectrum disorder. International Journal of Disability, Development and Education, 56, 381-399. doi:10.1080/10349120903306715

Potter, J., \& Hepburn, A. (2005). Qualitative interviews in psychology: Problems and possibilities. Qualitative Research in Psychology, 2, 281-307. doi:10.1191/1478088705qp045oa

Rager, K. B. (2005a). Compassion stress and the qualitative researcher. Qualitative Health Research, 15, 423-430. doi:10.1177/1049732304272038

Rager, K. B. (2005b). Self-care and the qualitative researcher: When collecting data can break your heart. Educational Researcher, 34(4), 23-27. doi:10.3102/0013189X034004023

Sachse, M., Schlitt, S., Hainz, D., Ciaramidaro, A., Schirman, S., Walter, H., ... Freitag, C. M. (2013). Executive and visuo-motor function in adolescents and adults with autism spectrum disorder. Journal of Autism and Developmental Disorders, 43, 1222-1235. doi:10.1007/s10803-012-1668-8

Sandelowski, M. (1995). Qualitative analysis: What it is and how to begin. Research in Nursing \& Health, 18, 371-375. doi:10.1002/nur.4770180411

Seligman, M., \& Darling, R. B. (2007). Ordinary families, special children: A systems approach to childhood disability (3rd ed.). New York, NY: Guilford Press.

Solomon, M., Miller, M., Taylor, S. L., Hinshaw, S. P., \& Carter, C. S. (2012). Autism symptoms and internalizing psychopathology in girls and boys with autism spectrum 
disorders. Journal of Autism and Developmental Disorders, 42, 48-59. doi:10.1007/s10803-011-1215-Z

Stamm, B. H. (1999). Secondary traumatic stress: Self-care issues for clinicians, researchers, and educators (2nd ed.). Lutherville, MD: Sidran Press.

van den Hoonaard, W. C. (Ed.). (2002). Walking the tightrope: Ethical issues for qualitative researchers. Toronto, Canada: University of Toronto Press. 
Table 1. Recommendations

\begin{tabular}{|c|c|c|c|c|}
\hline & Research stage & Recommendation & General rationale & Rationale for ASD research \\
\hline 1a. & $\begin{array}{l}\text { Preparation: } \\
\text { Interview guide } \\
\text { development }\end{array}$ & \begin{tabular}{ll|} 
Include an \\
introductory \\
statement.
\end{tabular} & $\begin{array}{l}\text { An introductory statement before commencing } \\
\text { the interview can be helpful in reminding } \\
\text { participants about the general content of the } \\
\text { interview and the expected length of the } \\
\text { interview. It may also facilitate a clear and } \\
\text { concise introduction to the interview process. }\end{array}$ & $\begin{array}{l}\text { An introductory statement may be particularly } \\
\text { relevant for individuals with ASD given their } \\
\text { general preference for preparedness (Solomon, } \\
\text { Miller, Taylor, Hinshaw, \& Carter, 2012). }\end{array}$ \\
\hline $1 \mathrm{~b}$. & \begin{tabular}{l|} 
Preparation: \\
Interview guide \\
development
\end{tabular} & $\begin{array}{l}\text { Begin interviews } \\
\text { with a “warm-up” } \\
\text { question. }\end{array}$ & $\begin{array}{l}\text { A warm-up question will "set the scene" for the } \\
\text { interview while also allowing participants to } \\
\text { experience mastery and relax into the interview. } \\
\text { Example warm-up questions may be "Tell me } \\
\text { who is in your family" or "What activities do } \\
\text { you like doing with your family?" }\end{array}$ & $\begin{array}{l}\text { Initial nervousness may be of particular relevance } \\
\text { when interviewing individuals with ASD due to } \\
\text { the social and communicative impairments } \\
\text { associated with their condition (Cridland, Caputi, } \\
\text { Jones, \& Magee, 2014; Solomon et al., 2012). }\end{array}$ \\
\hline 1c. & $\begin{array}{l}\text { Preparation: } \\
\text { Interview guide } \\
\text { development }\end{array}$ & $\begin{array}{l}\text { Provide a prelude } \\
\text { to challenging } \\
\text { questions. }\end{array}$ & $\begin{array}{l}\text { A prelude prepares participants for the upcoming } \\
\text { question and normalises any feelings of } \\
\text { confusion or discomfort they may have. An } \\
\text { example of a prelude is, "Some people find the } \\
\text { next few questions difficult...". }\end{array}$ & $\begin{array}{l}\text { There are topics that individuals with ASD are } \\
\text { likely to find challenging to talk about, such as } \\
\text { discussing abstract concepts, social difficulties, } \\
\text { emotions, perspective talking, etc. A prelude to } \\
\text { challenging questions may help prepare } \\
\text { participants with ASD and their families for } \\
\text { questions they may find difficult. }\end{array}$ \\
\hline $1 \mathrm{~d}$. & $\begin{array}{l}\text { Preparation: } \\
\text { Interview guide } \\
\text { development }\end{array}$ & $\begin{array}{l}\text { Structure interview } \\
\text { guide to have } \\
\text { challenging } \\
\text { questions followed } \\
\text { by easier topics. }\end{array}$ & $\begin{array}{l}\text { Oscillating between challenging and less } \\
\text { challenging topics can help reduce the emotional } \\
\text { and psychological demands of the interview on } \\
\text { participants. }\end{array}$ & $\begin{array}{l}\text { Efficacious "easy" questions should either aim to } \\
\text { foster mastery without beginning a lengthy } \\
\text { conversation or relate in some way to the research } \\
\text { topic (Minichiello et al., 1995). Easy questions for } \\
\text { individuals with ASD about hobbies or special } \\
\text { interests are best avoided as they may lead to } \\
\text { lengthy conversations of little relevance to the } \\
\text { focus of the study. It may also be difficult to } \\
\text { redirect participants back to the interview. }\end{array}$ \\
\hline
\end{tabular}




\begin{tabular}{|c|c|c|c|c|}
\hline $1 \mathrm{e}$. & $\begin{array}{l}\text { Preparation: } \\
\text { Interview guide } \\
\text { development }\end{array}$ & $\begin{array}{l}\text { Develop single- } \\
\text { faceted questions. }\end{array}$ & $\begin{array}{l}\text { Single-faceted questions are easier for } \\
\text { participants to understand and accurately } \\
\text { interpret. Examples of single faceted questions } \\
\text { are, "What are your favourite subjects at } \\
\text { school?" and "How do you find homework?" } \\
\text { This is opposed to a multifaceted format: "What } \\
\text { are your favourite subjects at school and how do } \\
\text { you find homework?" }\end{array}$ & $\begin{array}{l}\text { Single-faceted questions suit the processing style } \\
\text { of participants with ASD and facilitate accurate } \\
\text { interpretation of the question (Cridland, Caputi, et } \\
\text { al., 2014; Solomon et al., 2012). }\end{array}$ \\
\hline 1f. & $\begin{array}{l}\text { Preparation: } \\
\text { Interview guide } \\
\text { development }\end{array}$ & $\begin{array}{l}\text { Use both positively } \\
\text { and negatively } \\
\text { framed questions. }\end{array}$ & $\begin{array}{l}\text { Using positively and negatively framed } \\
\text { questions facilitates discussion of both rewarding } \\
\text { and challenging experiences, attitudes, and } \\
\text { feelings, which contributes to a balanced } \\
\text { understanding of issues. }\end{array}$ & $\begin{array}{l}\text { It is recognised that living in a family with ASD } \\
\text { involves both rewarding and challenging } \\
\text { experiences, attitudes, and feelings (Cridland, } \\
\text { Jones, et al., 2014; Davis \& Gavidia-Payne, 2009; } \\
\text { Pakenham et al., 2005) and these issues need } \\
\text { investigation. In doing so, it may be important to } \\
\text { acknowledge that not all participants will share the } \\
\text { range of experiences. A prelude such as "Some } \\
\text { people find positive aspects of living with ASD. } \\
\text { Have you experienced this?" may help normalise } \\
\text { discussion of challenging aspects of living with } \\
\text { ASD and encourage open discussion. }\end{array}$ \\
\hline 1g. & $\begin{array}{l}\text { Preparation: } \\
\text { Interview guide } \\
\text { development }\end{array}$ & $\begin{array}{l}\text { Avoid using } \\
\text { leading questions. }\end{array}$ & $\begin{array}{l}\text { All research studies have aims and hypotheses; } \\
\text { however, it is important that interview questions } \\
\text { do not elicit responses solely in support of these } \\
\text { hypotheses. An example of a leading question in } \\
\text { a study focusing on the challenges of } \\
\text { transitioning to high school would be, "What } \\
\text { have been the hardest parts of transitioning to } \\
\text { high school?" An example of a "neutral" } \\
\text { question for investigation of this issue would be, } \\
\text { "What has been your experience of transitioning } \\
\text { to high school?" }\end{array}$ & $\begin{array}{l}\text { When responding to questions, individuals with } \\
\text { ASD may be more likely to provide answers that } \\
\text { are specific to the question posed rather than using } \\
\text { that question as a platform on which to elaborate, } \\
\text { as NTD participants may. Therefore, continuing } \\
\text { with the current example, if participants with ASD } \\
\text { are asked about the challenges of high school they } \\
\text { are likely to only discuss challenges even if they } \\
\text { think there are also positive aspects (Cridland, } \\
\text { Caputi, et al., 2014). }\end{array}$ \\
\hline 1h. & $\begin{array}{l}\text { Preparation: } \\
\text { Interview guide } \\
\text { development }\end{array}$ & $\begin{array}{l}\text { Pilot test the } \\
\text { interview guide. }\end{array}$ & $\begin{array}{l}\text { Pilot testing the interview guide is helpful in } \\
\text { estimating the time needed to conduct the } \\
\text { interview and promote researcher familiarity } \\
\text { with the interview guide. }\end{array}$ & $\begin{array}{l}\text { Pilot testing with an individual with ASD may be } \\
\text { useful in identifying questions that may be } \\
\text { confusing or open to misinterpretation. }\end{array}$ \\
\hline
\end{tabular}




\begin{tabular}{|c|c|c|c|c|}
\hline 1i. & $\begin{array}{l}\text { Preparation: } \\
\text { Participant } \\
\text { recruitment }\end{array}$ & $\begin{array}{l}\text { Provide multiple } \\
\text { methods of contact } \\
\text { when advertising } \\
\text { the study. }\end{array}$ & $\begin{array}{l}\text { Providing multiple methods of contacting the } \\
\text { research team gives participants flexibility in } \\
\text { response options. Methods of contact may } \\
\text { include text message services, email, or social } \\
\text { media such as Facebook. }\end{array}$ & $\begin{array}{l}\text { Some methods of contact (such as emails) may be } \\
\text { less socially demanding on individuals with ASD, } \\
\text { which may encourage better response rates to the } \\
\text { study. Additionally, options such as text messages } \\
\text { may be less time demanding for family members. }\end{array}$ \\
\hline $1 \mathrm{j}$. & $\begin{array}{l}\text { Preparation: } \\
\text { Participant } \\
\text { recruitment }\end{array}$ & $\begin{array}{l}\text { Provide clear and } \\
\text { detailed } \\
\text { information about } \\
\text { the study in } \\
\text { recruitment } \\
\text { information. }\end{array}$ & $\begin{array}{l}\text { Providing participants with transparent and } \\
\text { detailed information about the study during } \\
\text { recruitment may encourage potential participants } \\
\text { to respond to the study advertisement. Such } \\
\text { information may include study aims, participant } \\
\text { requirements, study timeframe (e.g., recruitment } \\
\text { cut-off, data collection phases, etc.), and } \\
\text { expected benefits to participants. }\end{array}$ & $\begin{array}{l}\text { Providing detailed study information when } \\
\text { recruiting individuals with ASD may improve } \\
\text { response rates. This is likely to be associated with } \\
\text { the social and communicative impairments } \\
\text { inherent with ASD. }\end{array}$ \\
\hline $1 \mathrm{k}$. & $\begin{array}{l}\text { tion: } \\
\text { ant } \\
\text { ent }\end{array}$ & $\begin{array}{l}\text { Employ some } \\
\text { nontraditional } \\
\text { recruitment } \\
\text { approaches. }\end{array}$ & $\begin{array}{l}\text { Employing some nontraditional recruitment } \\
\text { approaches will increase the number of potential } \\
\text { participants that the study is advertised to. }\end{array}$ & $\begin{array}{l}\text { Approaches that may be effective when recruiting } \\
\text { families living with ASD include attending } \\
\text { community ASD support groups, outlining the } \\
\text { study to school teachers so that they can } \\
\text { personally provide information to families of } \\
\text { students with ASD enrolled in their school, and } \\
\text { snowballing from recruited participants. }\end{array}$ \\
\hline 11. & $\begin{array}{l}\text { tion: } \\
\text { ant } \\
\text { lent }\end{array}$ & $\begin{array}{l}\text { Include } \\
\text { information about } \\
\text { the expected } \\
\text { positive outcomes } \\
\text { of being involved } \\
\text { in the study. }\end{array}$ & $\begin{array}{l}\text { Being involved in qualitative research has been } \\
\text { found to be a rewarding and enriching } \\
\text { experience for participants (Dickson-Swift et al., } \\
\text { 2007, 2008; Dockett et al., 2009; Rager, 2005a, } \\
\text { 2005b). Sharing this information with potential } \\
\text { participants may increase their interest in being } \\
\text { involved in the study. }\end{array}$ & $\begin{array}{l}\text { The positive outcomes of being involved in } \\
\text { qualitative research for families living with ASD } \\
\text { may include having an opportunity to discuss } \\
\text { issues important to them, developing greater } \\
\text { awareness and understanding of family member's } \\
\text { perspectives, and having an opportunity to "give } \\
\text { back" to the ASD community. }\end{array}$ \\
\hline $1 \mathrm{~m}$ & $\begin{array}{l}\text { Preparation: } \\
\text { Obtaining } \\
\text { informed and } \\
\text { voluntary } \\
\text { assent/consent }\end{array}$ & $\begin{array}{lr}\text { Organise } & \text { a } \\
\text { "preliminary } & \\
\text { meeting" } & \text { with } \\
\text { potential families } & \\
\text { to outline the study. }\end{array}$ & $\begin{array}{l}\text { A preliminary meeting is useful for providing } \\
\text { potential participants with written and verbal } \\
\text { information about the study and requirements of } \\
\text { participants (e.g., time commitment). It is also } \\
\text { useful for answering participant questions and } \\
\text { ensuring that research eligibility criteria are } \\
\text { satisfied. }\end{array}$ & $\begin{array}{l}\text { During this meeting it may be useful to ask what } \\
\text { terminology a family uses to refer to the ASD } \\
\text { diagnosis (e.g., autism, Asperger's, Aspie, etc.) } \\
\text { and ensure that all relevant family members have } \\
\text { knowledge of the ASD diagnosis. }\end{array}$ \\
\hline 1n. & Preparation: & informed & While written assent from child participants is & Child participants in this research area include \\
\hline
\end{tabular}




\begin{tabular}{|c|c|c|c|c|}
\hline & $\begin{array}{l}\text { Obtaining } \\
\text { informed and } \\
\text { voluntary } \\
\text { assent/consent }\end{array}$ & $\begin{array}{l}\text { assent from child } \\
\text { participants. }\end{array}$ & $\begin{array}{l}\text { not always necessary to fulfil ethical } \\
\text { requirements of research (Agre \& Rapkin, 2003; } \\
\text { van den Hoonard, 2002), its inclusion is } \\
\text { important to ensure all participants are } \\
\text { voluntarily participating in the study. }\end{array}$ & $\begin{array}{l}\text { children with ASD and NTD siblings. If using } \\
\text { assent forms for children with ASD a "checklist" } \\
\text { format may be appropriate as participant } \\
\text { requirements can be clearly outlined. }\end{array}$ \\
\hline 10. & $\begin{array}{l}\text { Preparation: } \\
\text { Obtaining } \\
\text { informed and } \\
\text { voluntary } \\
\text { assent/consent }\end{array}$ & $\begin{array}{l}\text { Remind } \\
\text { participants of the } \\
\text { research aims and } \\
\text { participant } \\
\text { commitments at } \\
\text { each contact. }\end{array}$ & $\begin{array}{l}\text { Discussing research aims and participant } \\
\text { commitments regularly facilitates informed and } \\
\text { voluntary assent/consent. These discussions may } \\
\text { involve providing participants with a study } \\
\text { information sheet and/or consent form and } \\
\text { asking if they would like to continue their } \\
\text { involvement in the study. }\end{array}$ & $\begin{array}{l}\text { Ongoing consent is of particular relevance when } \\
\text { involving individuals with ASD in research, as } \\
\text { they may have additional queries about the study } \\
\text { which they may not raise unless overtly given the } \\
\text { opportunity. }\end{array}$ \\
\hline 1p. & $\begin{array}{l}\text { Preparation: } \\
\text { Obtaining } \\
\text { informed and } \\
\text { voluntary } \\
\text { assent/consent }\end{array}$ & $\begin{array}{l}\text { When conducting } \\
\text { research with } \\
\text { families, ensure } \\
\text { consent is obtained } \\
\text { from individual } \\
\text { family members. }\end{array}$ & $\begin{array}{l}\text { Although parents/carers may be the family } \\
\text { members who initially show interest in the study, } \\
\text { it is important that they do not provide consent } \\
\text { on behalf of other members of their family. } \\
\text { Additionally, we advise against requiring all } \\
\text { family members to be involved in the study in } \\
\text { order for a family to be eligible for study } \\
\text { participation. This flexibility will reduce the } \\
\text { possibility of some family members feeling } \\
\text { pressured to provide consent and also reduce the } \\
\text { number of families deemed ineligible for the } \\
\text { study. }\end{array}$ & $\begin{array}{l}\text { Individualised consent procedures are equally } \\
\text { important in families living with ASD. Further, } \\
\text { the literature highlights that individuals with ASD } \\
\text { (Cocks, 2008) and children (e.g., NTD siblings) } \\
\text { (Mishna et al., 2004; Potter \& Hepburn, 2005) are } \\
\text { particularly vulnerable subgroups in having their } \\
\text { consent provided for them. }\end{array}$ \\
\hline $1 \mathrm{q}$. & $\begin{array}{l}\text { Preparation: } \\
\text { Obtaining } \\
\text { informed and } \\
\text { voluntary } \\
\text { assent/consent }\end{array}$ & $\begin{array}{l}\text { When conducting } \\
\text { research with } \\
\text { families, clearly } \\
\text { outline } \\
\text { confidentiality } \\
\text { procedures. }\end{array}$ & $\begin{array}{l}\text { Clearly outlining confidentiality issues ensures } \\
\text { participants are aware that information provided } \\
\text { during interviews will not be shared with other } \\
\text { family members (unless the study has an open } \\
\text { nature). This awareness may encourage openness } \\
\text { during the interviews and prevent participants } \\
\text { asking about other family members' responses. }\end{array}$ & $\begin{array}{l}\text { Participants may feel reluctant to speak openly } \\
\text { about the challenging aspects of living with ASD } \\
\text { if they are uncertain whether their interviews will } \\
\text { be shared with other family members. This may } \\
\text { result in denial or minimisation of such topics. }\end{array}$ \\
\hline
\end{tabular}




\begin{tabular}{|c|c|c|c|c|}
\hline 2a. & $\begin{array}{l}\text { Data collection: } \\
\text { Appropriate } \\
\text { interview } \\
\text { settings }\end{array}$ & \begin{tabular}{lr|} 
Ensure & home \\
interviews & are \\
conducted in an \\
appropriate & private \\
space. &
\end{tabular} & $\begin{array}{l}\text { Conducting home interviews in an appropriate } \\
\text { private space, such as a quiet living area or } \\
\text { study, ensures confidentiality of information } \\
\text { shared. Additionally, there will be fewer } \\
\text { distractions for participants and a quiet } \\
\text { environment for clear recording (if used). }\end{array}$ & $\begin{array}{l}\text { Conducting home interviews in a private space } \\
\text { may facilitate discussion of challenging issues, } \\
\text { such as the difficulties of living in a family with } \\
\text { ASD, which participants may otherwise feel } \\
\text { hindered to discuss openly if they felt family } \\
\text { members could overhear. }\end{array}$ \\
\hline 2b. & $\begin{array}{l}\text { Data collection: } \\
\text { Appropriate } \\
\text { interview } \\
\text { settings }\end{array}$ & $\begin{array}{l}\text { Consider using an } \\
\text { alternative venue if } \\
\text { home interviews } \\
\text { are not appropriate. }\end{array}$ & $\begin{array}{l}\text { Alternative venues should be considered if there } \\
\text { is no appropriate space within the family home } \\
\text { (e.g., open-plan living, strained family } \\
\text { relationships, etc.), or if participants and/or the } \\
\text { researcher do not feel comfortable or safe } \\
\text { conducting the interview within the home. } \\
\text { Suitable venues include a quiet room in the } \\
\text { researchers' workplace or a bookable room in a } \\
\text { community building, such as a library. }\end{array}$ & $\begin{array}{l}\text { Alternative venues may need to be considered if } \\
\text { interviews involve discussion of difficult topics } \\
\text { associated with living with ASD, and the } \\
\text { researcher or participant feel it is more appropriate } \\
\text { to discuss these outside the family home. Safety } \\
\text { issues of particular relevance when conducting } \\
\text { interviews with individuals with ASD involve } \\
\text { unexpected responses or behavioural reactions. } \\
\text { For example, a participant may become highly } \\
\text { aroused if feeling confused about a question or } \\
\text { feeling uncomfortable about discussing a } \\
\text { particular topic. Strategies to promote a safe } \\
\text { environment include conducting the interviews } \\
\text { with two researchers (a primary researcher } \\
\text { conducting the interview and a second to observe } \\
\text { or scribe), and/or ensuring a parent/carer is } \\
\text { available but not present. }\end{array}$ \\
\hline 2c. & $\begin{array}{l}\text { Data collection: } \\
\text { Practicalities of } \\
\text { conducting } \\
\text { interviews }\end{array}$ & $\begin{array}{l}\text { Schedule } \\
\text { interviews at a } \\
\text { preferred time for } \\
\text { participants. }\end{array}$ & $\begin{array}{l}\text { Participants are more likely to be engaged in the } \\
\text { interview process if it is conducted at a time } \\
\text { suitable for them. } \\
\text { In order to conduct interviews at appropriate } \\
\text { timeslots, researchers may need to be flexible, } \\
\text { which may include conducting interviews } \\
\text { outside of business hours (such as on weekends). }\end{array}$ & $\begin{array}{l}\text { The engagement of participants with ASD may be } \\
\text { particularly influenced by the timing. For } \\
\text { example, mornings may be identified as a "good" } \\
\text { time for an interview rather than shortly after } \\
\text { school or work when the participant may be } \\
\text { stressed or tired. } \\
\text { Additionally, contacting participants with ASD } \\
\text { before the interview to check the arranged time is } \\
\text { still appropriate is recommended. Rescheduling if } \\
\text { needed is important, as conducting an interview } \\
\text { with an individual with ASD who is not in an } \\
\text { appropriate frame of mind may result in tainted }\end{array}$ \\
\hline
\end{tabular}




\begin{tabular}{|c|c|c|c|c|}
\hline & & & & $\begin{array}{l}\text { responses (e.g., negatively framed responses or } \\
\text { lack of responses). }\end{array}$ \\
\hline $2 \mathrm{~d}$. & $\begin{array}{l}\text { Data collection: } \\
\text { Practicalities of } \\
\text { conducting } \\
\text { interviews }\end{array}$ & $\begin{array}{l}\text { Allow ample time } \\
\text { when travelling to } \\
\text { interviews to } \\
\text { ensure punctuality. }\end{array}$ & $\begin{array}{l}\text { Apart from a general sign of courtesy, } \\
\text { punctuality portrays a professional attitude } \\
\text { toward the research. Arriving on time is also a } \\
\text { sign of respect for the participant's time } \\
\text { commitment of being involved in the study. }\end{array}$ & $\begin{array}{l}\text { Punctuality may be of particular relevance for } \\
\text { interviews with individuals with ASD, as they } \\
\text { may become agitated or upset if the researcher is } \\
\text { late. }\end{array}$ \\
\hline 2e. & $\begin{array}{l}\text { Data collection: } \\
\text { Practicalities of } \\
\text { conducting } \\
\text { interviews }\end{array}$ & $\begin{array}{l}\text { Take time to build } \\
\text { rapport } \quad \text { with } \\
\text { participants. }\end{array}$ & $\begin{array}{l}\text { The importance of rapport building in qualitative } \\
\text { research is well established (Brinkmann, 2007; } \\
\text { Lavis, 2010; van den Hoonaard, 2002). } \\
\text { However, in building rapport it is important to } \\
\text { not just "do" rapport, where the researcher } \\
\text { engages in "faking friendship" to obtain } \\
\text { knowledge from the participant (Brinkmann, } \\
\text { 2007). }\end{array}$ & $\begin{array}{l}\text { Rapport building is essential in this research area } \\
\text { given the highly personal nature of research } \\
\text { topics. Rapport with families living with ASD is } \\
\text { likely to be established by showing a genuine } \\
\text { interest in their experiences, having an open } \\
\text { attitude throughout the interview, and regarding } \\
\text { the participant as the expert on the interview topic. }\end{array}$ \\
\hline 2f. & $\begin{array}{l}\text { Data collection: } \\
\text { Practicalities of } \\
\text { conducting } \\
\text { interviews }\end{array}$ & $\begin{array}{lr}\text { Be aware } & \text { of } \text { your } \\
\text { rate of } & \text { speech } \\
\text { when } & \text { asking } \\
\text { interview } & \\
\text { questions. }\end{array}$ & $\begin{array}{l}\text { Asking interview questions in a measured, slow } \\
\text { pace facilitates accurate interpretation. }\end{array}$ & $\begin{array}{l}\text { A slower pace of information presentation has } \\
\text { been shown to suit the processing style of } \\
\text { individuals with ASD (Deruelle, Rondan, Gepner, } \\
\text { \& Fagot, 2006; Myles \& Simpson, 1998; Sachse } \\
\text { et al., 2013). } \\
\text { Related to this, individuals with ASD may require } \\
\text { a longer length of time to provide an answer to } \\
\text { interview questions (Deruelle et al., 2006) and } \\
\text { researchers should allow ample time for a } \\
\text { participant to respond before checking in that they } \\
\text { understood the question. }\end{array}$ \\
\hline 2g. & $\begin{array}{l}\text { Data collection: } \\
\text { Practicalities of } \\
\text { conducting } \\
\text { interviews }\end{array}$ & \begin{tabular}{ll|} 
Consider & video- \\
recording & \\
interviews. &
\end{tabular} & $\begin{array}{l}\text { The benefit of using video recordings over voice } \\
\text { recordings is the ability to analyse both verbal } \\
\text { and visual information (e.g., facial expression, } \\
\text { hand gestures, body movements, etc.). }\end{array}$ & $\begin{array}{l}\text { Video-recording interviews is an emerging } \\
\text { methodological approach in this field } \\
\text { (Meirsschaut, Roeyers, \& Warreyn, 2011; } \\
\text { Mossman Steiner, 2011; Naber et al., 2008). The } \\
\text { benefits of this approach when interviewing } \\
\text { participants with ASD includes ability to analyse } \\
\text { inconsistencies between verbal responses and } \\
\text { body language, individualised uses of hand }\end{array}$ \\
\hline
\end{tabular}




\begin{tabular}{|c|c|c|c|c|}
\hline & & & & gestures, and use of eye contact. \\
\hline $2 \mathrm{~h}$. & $\begin{array}{l}\text { Data collection: } \\
\text { Practicalities of } \\
\text { conducting } \\
\text { interviews }\end{array}$ & $\begin{array}{l}\text { Leave recording } \\
\text { device going until } \\
\text { the interview has } \\
\text { come to an } \\
\text { absolute } \\
\text { conclusion. }\end{array}$ & $\begin{array}{l}\text { Participants may continue to speak after the last } \\
\text { interview question and useful information may } \\
\text { be missed if not recorded. }\end{array}$ & $\begin{array}{l}\text { Participants often continue to share their } \\
\text { experiences of living in a family with ASD after } \\
\text { the interview. }\end{array}$ \\
\hline 3a. & $\begin{array}{l}\text { Data analysis: } \\
\text { Accurate } \\
\text { analysis and } \\
\text { interpretation of } \\
\text { data }\end{array}$ & $\begin{array}{l}\text { Transcribe } \\
\text { interviews rather } \\
\text { than use scribes. }\end{array}$ & $\begin{array}{l}\text { Transcribing has been considered an integral } \\
\text { component of preliminary data analysis (van den } \\
\text { Hoonaard, 2002). Transcribing is also an } \\
\text { important way to improve interview techniques, } \\
\text { such as the wording of questions, smooth } \\
\text { transitioning between topics, and beginning and } \\
\text { concluding the interview. }\end{array}$ & $\begin{array}{l}\text { Improving interview techniques as a result of } \\
\text { transcribing may be particularly important when } \\
\text { interviewing individuals with ASD, given the } \\
\text { heightened importance of appropriate wording of } \\
\text { questions and suitable beginnings and conclusions } \\
\text { of interviews with these individuals. }\end{array}$ \\
\hline 3b. & $\begin{array}{l}\text { Data analysis: } \\
\text { Accurate } \\
\text { analysis and } \\
\text { interpretation of } \\
\text { data }\end{array}$ & $\begin{array}{l}\text { Attend to issues } \\
\text { that participants do } \\
\text { not discuss. }\end{array}$ & $\begin{array}{l}\text { There is a focus on what a participant says in } \\
\text { qualitative research. However, it is also } \\
\text { important to reflect on issues participants do not } \\
\text { discuss. Participants may not discuss issues due } \\
\text { to legitimate irrelevance of a topic, minimal } \\
\text { rapport with the researcher, or a desire to portray } \\
\text { a certain image during the interview. }\end{array}$ & $\begin{array}{l}\text { Participants may find it difficult or even taboo to } \\
\text { discuss the challenges of living in a family with } \\
\text { ASD. Similarly, participants may wish to portray } \\
\text { an image of resilience or positivity by focusing on } \\
\text { the rewarding aspects of living in a family with } \\
\text { ASD. }\end{array}$ \\
\hline 3c. & $\begin{array}{l}\text { Data analysis: } \\
\text { Accurate } \\
\text { analysis and } \\
\text { interpretation of } \\
\text { data }\end{array}$ & $\begin{array}{l}\text { Have multiple } \\
\text { researchers } \quad \text { code } \\
\text { the data. }\end{array}$ & $\begin{array}{l}\text { The credibility of qualitative data analysis is } \\
\text { improved with multiple researchers coding the } \\
\text { data (Barnes, 1992; Braun \& Clarke, 2006). The } \\
\text { process of coding with multiple researchers } \\
\text { includes a primary researcher conducting, } \\
\text { transcribing, and analysing the data, while other } \\
\text { members of the research team read, and } \\
\text { independently code the data for comparison } \\
\text { (Braun \& Clarke, 2006). }\end{array}$ & $\begin{array}{l}\text { Multiple coders are important when conducting } \\
\text { research with families living with ASD because it } \\
\text { is common for researchers in this field to have } \\
\text { strong connections and investment with the } \\
\text { research topic (Potter \& Hepburn, 2005) and this } \\
\text { background may interfere with objective data } \\
\text { analysis. It is important that researchers are aware } \\
\text { of their potential for bias (Brinkmann, 2007; van } \\
\text { den Hoonaard, 2002). }\end{array}$ \\
\hline 3d. & $\begin{array}{l}\text { Data analysis: } \\
\text { Accurate } \\
\text { analysis and } \\
\text { interpretation of } \\
\text { data }\end{array}$ & $\begin{array}{l}\text { Use analytical } \\
\text { techniques that } \\
\text { model the } \\
\text { characteristics of } \\
\text { family data. }\end{array}$ & $\begin{array}{l}\text { In using analytical techniques that model the } \\
\text { characteristics of family data researchers are able } \\
\text { to gain insights into interpersonal relationships } \\
\text { within the family, in addition to the perceptions } \\
\text { from individual family members. }\end{array}$ & $\begin{array}{l}\text { In researching families living with ASD there may } \\
\text { be discrepant perceptions across family members } \\
\text { (e.g., a sibling reporting that they take on } \\
\text { significant caregiving responsibilities, whereas } \\
\text { parental reports indicate they do not contribute }\end{array}$ \\
\hline
\end{tabular}




\begin{tabular}{|c|c|c|c|c|}
\hline & & & & enough). These issues are worthy of investigation. \\
\hline 3e. & $\begin{array}{l}\text { Data analysis: } \\
\text { Involving } \\
\text { participants in } \\
\text { data analysis }\end{array}$ & $\begin{array}{l}\text { Include participants } \\
\text { in data analysis. }\end{array}$ & $\begin{array}{l}\text { Including participants in data analysis may } \\
\text { involve giving participants the opportunity to } \\
\text { read their own transcripts (member checks), and } \\
\text { encouraging participants to brainstorm "themes" } \\
\text { emerging from their interviews. In addition, } \\
\text { participants may be invited to read drafts of } \\
\text { reports and provide feedback to researchers. }\end{array}$ & $\begin{array}{l}\text { Including individuals with ASD and their families } \\
\text { in data analysis is in line with recommendations in } \\
\text { the literature (Cocks, 2008; Dockett et al., 2009; } \\
\text { Mishna et al., 2004). The benefits of including } \\
\text { these participants in data analysis include giving } \\
\text { participants the opportunity to reflect on their } \\
\text { interviews, develop ownership of their data, and } \\
\text { an appreciation of the research process. Further, } \\
\text { some participants may find this process rewarding } \\
\text { and therapeutic. }\end{array}$ \\
\hline 4a. & $\begin{array}{l}\text { Dissemination } \\
\text { of findings: } \\
\text { Effective } \\
\text { communication } \\
\text { of research } \\
\text { findings }\end{array}$ & $\begin{array}{l}\text { Provide feedback } \\
\text { about the study's } \\
\text { findings to relevant } \\
\text { individuals and } \\
\text { community groups. }\end{array}$ & $\begin{array}{l}\text { The benefits of providing feedback to relevant } \\
\text { individuals and community groups include } \\
\text { sharing of research information and fostering } \\
\text { networks, which may be used in future research } \\
\text { endeavours. }\end{array}$ & $\begin{array}{l}\text { Relevant individuals and community groups for } \\
\text { research focusing on individuals with ASD may } \\
\text { include local ASD community groups, ASD } \\
\text { research centres, as well as mainstream and ASD- } \\
\text { specific schools. }\end{array}$ \\
\hline 4b. & $\begin{array}{l}\text { Dissemination } \\
\text { of findings: } \\
\text { Effective } \\
\text { communication } \\
\text { of research } \\
\text { findings }\end{array}$ & $\begin{array}{lr}\text { Consider } & \text { target } \\
\text { audience } & \text { when } \\
\text { choosing journals } \\
\text { to publish research } \\
\text { findings. }\end{array}$ & $\begin{array}{l}\text { To facilitate effective communication of research } \\
\text { findings, it is important to consider the intended } \\
\text { target audience of the research when choosing } \\
\text { journals to publish in rather than focusing on } \\
\text { other research criteria such as the prestige of the } \\
\text { journal. Additionally, be prepared that the target } \\
\text { audience may change over the course of the } \\
\text { research. }\end{array}$ & $\begin{array}{l}\text { Target audiences for research focusing on } \\
\text { individuals with ASD may include families, } \\
\text { clinicians, health practitioners, teachers, } \\
\text { policymakers, etc. }\end{array}$ \\
\hline 4c. & $\begin{array}{l}\text { Dissemination } \\
\text { of findings: } \\
\text { Effective } \\
\text { communication } \\
\text { of research } \\
\text { findings }\end{array}$ & $\begin{array}{l}\text { Consider } \\
\text { presenting findings } \\
\text { to community } \\
\text { members. }\end{array}$ & $\begin{array}{l}\text { Academic journals and conferences have their } \\
\text { place in disseminating research findings; } \\
\text { however, it may be efficacious to also pursue } \\
\text { other avenues when disseminating findings to } \\
\text { the broader community. Such avenues may } \\
\text { include community forums, radio stations, and } \\
\text { newspapers and/or television news programs. }\end{array}$ & $\begin{array}{l}\text { When disseminating research findings to } \\
\text { community members interested in ASD research it } \\
\text { may be efficacious to present findings to local } \\
\text { ASD community groups, forums, etc. } \\
\text { Additionally, when using mainstream media } \\
\text { avenues, it may be useful to advertise upcoming } \\
\text { programs through local ASD community groups. }\end{array}$ \\
\hline 4d. & $\begin{array}{l}\text { Dissemination } \\
\text { of findings: } \\
\text { Providing }\end{array}$ & $\begin{array}{l}\text { Provide } \\
\text { participants with } \\
\text { written feedback }\end{array}$ & $\begin{array}{l}\text { Information sheets are an appropriate method for } \\
\text { providing feedback to participants because they } \\
\text { provide a succinct outline of information, they }\end{array}$ & $\begin{array}{l}\text { When developing information sheets for } \\
\text { individuals with ASD, a structured format (i.e., } \\
\text { use of headings, bullet points, etc.) may facilitate }\end{array}$ \\
\hline
\end{tabular}




\begin{tabular}{|c|c|c|c|c|}
\hline & $\begin{array}{l}\text { feedback } \\
\text { participants }\end{array}$ & $\begin{array}{l}\text { about the study's } \\
\text { findings. }\end{array}$ & $\begin{array}{l}\text { are a tangible resource for participants to refer } \\
\text { to, and they are economical and practical. } \\
\text { The main drawback of information sheets is that } \\
\text { they may be considered impersonal. }\end{array}$ & $\begin{array}{l}\text { their understanding of the information. } \\
\text { Additionally, it may be useful to provide } \\
\text { information about local ASD community groups } \\
\text { for participants who do not access support } \\
\text { services. }\end{array}$ \\
\hline 4e. & $\begin{array}{l}\text { Dissemination } \\
\text { of findings: } \\
\text { Providing } \\
\text { feedback to } \\
\text { participants }\end{array}$ & $\begin{array}{l}\text { Provide } \\
\text { participants with } \\
\text { the opportunity to } \\
\text { come to a group } \\
\text { feedback session. }\end{array}$ & $\begin{array}{l}\text { Group feedback sessions are useful for } \\
\text { conveying in-depth findings and provide } \\
\text { participants with an opportunity ask questions } \\
\text { and provide comments. } \\
\text { Considerations when conducting feedback } \\
\text { sessions for families include running sessions at } \\
\text { various times/dates to cater for commitments } \\
\text { such as work and after-school activities, } \\
\text { providing a venue with suitable child minding } \\
\text { facilities, and providing written information for } \\
\text { participants who are unable to attend. }\end{array}$ & $\begin{array}{l}\text { A secondary benefit of group feedback sessions is } \\
\text { an opportunity for participants to interact with } \\
\text { other families living with ASD. The social support } \\
\text { provided by such feedback sessions may be } \\
\text { equally as important to participants as receiving } \\
\text { information about the outcomes of the study. }\end{array}$ \\
\hline 4f. & $\begin{array}{l}\text { Dissemination } \\
\text { of findings: } \\
\text { Providing } \\
\text { feedback to } \\
\text { participants }\end{array}$ & $\begin{array}{l}\text { Reflect on the } \\
\text { impact of being } \\
\text { involved in the } \\
\text { study } \\
\text { participants. with }\end{array}$ & $\begin{array}{l}\text { Reflections from the research team may include } \\
\text { professional and/or personal insights, and } \\
\text { challenges and rewards of conducting the } \\
\text { research. Additionally, reflections from the } \\
\text { research team acknowledge the significance of } \\
\text { participants sharing their experiences for the } \\
\text { research. }\end{array}$ & $\begin{array}{l}\text { Qualitative research investigating the experiences } \\
\text { of individuals with ASD and their families is } \\
\text { likely to involve participants sharing a range of } \\
\text { highly personal experiences, meaning that the } \\
\text { reflections from the research team about their } \\
\text { experiences of being involved in the research may } \\
\text { be particularly warranted. }\end{array}$ \\
\hline 5a. & $\begin{array}{l}\text { Researcher } \\
\text { health: } \\
\text { Importance } \\
\text { self-care }\end{array}$ & $\begin{array}{l}\text { Be involved in } \\
\text { debriefing sessions } \\
\text { to manage the } \\
\text { emotional impact } \\
\text { of conducting } \\
\text { qualitative } \\
\text { research. }\end{array}$ & $\begin{array}{l}\text { Debriefing sessions allow researchers to reflect } \\
\text { on challenging experiences, discuss ways of } \\
\text { improving research processes, and experience } \\
\text { moral support. Debriefing personnel may include } \\
\text { research team members and/or supervisors. } \\
\text { Importantly, debriefing sessions should not } \\
\text { replace professional support, which may be } \\
\text { necessary if researchers are seriously affected by } \\
\text { the study. }\end{array}$ & $\begin{array}{l}\text { Researchers should not underestimate the } \\
\text { emotional impact of conducting interviews with } \\
\text { individuals with ASD and their families. Reasons } \\
\text { for this include listening to difficult experiences, } \\
\text { being with participants who are emotional or have } \\
\text { behavioural outbursts, and providing a supportive } \\
\text { and nonjudgemental attitude throughout } \\
\text { interviews. }\end{array}$ \\
\hline $5 b$. & $\begin{array}{l}\text { Researcher } \\
\text { health: } \\
\text { Importance }\end{array}$ & $\begin{array}{l}\text { Maintain a journal } \\
\text { to manage the } \\
\text { emotional impact }\end{array}$ & $\begin{array}{l}\text { Journal keeping has been shown to help manage } \\
\text { the emotional impact of being involved in } \\
\text { qualitative research and also promote reflective }\end{array}$ & $\begin{array}{l}\text { As outlined in section 5a., managing the emotional } \\
\text { impact of conducting interviews with families } \\
\text { living with ASD is an important issue in this }\end{array}$ \\
\hline
\end{tabular}




\begin{tabular}{|c|c|c|c|c|}
\hline & self-care & $\begin{array}{l}\text { of conducting } \\
\text { qualitative } \\
\text { research. }\end{array}$ & $\begin{array}{l}\text { thinking that facilitates data interpretation } \\
\text { (Rager, 2005b). }\end{array}$ & $\begin{array}{l}\text { research area. Journal keeping may be one } \\
\text { strategy that assists with this. }\end{array}$ \\
\hline 5c. & $\begin{array}{l}\text { Researcher } \\
\text { health: } \\
\text { Importance of } \\
\text { self-care }\end{array}$ & $\begin{array}{l}\text { Space interviews } \\
\text { apart to manage the } \\
\text { emotional impact } \\
\text { of interviewing. }\end{array}$ & $\begin{array}{l}\text { Organising interviews over an extended period } \\
\text { may contribute to researcher self-care as it } \\
\text { reduces the intensity of conducting the } \\
\text { interviews and allows time for reflection } \\
\text { between interviews. }\end{array}$ & $\begin{array}{l}\text { Adequately spaced interviews may be particularly } \\
\text { warranted when conducting research with families } \\
\text { living with ASD given the range of emotionally } \\
\text { laded topics that may be inherent to the research } \\
\text { topic. }\end{array}$ \\
\hline $5 \mathrm{~d}$. & $\begin{array}{l}\text { Researcher } \\
\text { health: } \\
\text { Developing and } \\
\text { maintaining } \\
\text { healthy } \\
\text { boundaries }\end{array}$ & $\begin{array}{ll}\text { Be aware of the } \\
\text { potential } & \text { for } \\
\text { boundary } & \\
\text { confusions. } & \\
\end{array}$ & $\begin{array}{l}\text { Boundary confusion can occur when researchers } \\
\text { or participants become unclear around the } \\
\text { researchers primary role (which is to collect } \\
\text { data rather than being a friend or clinician). The } \\
\text { potential for boundary confusion is high in } \\
\text { qualitative research due to the personal nature of } \\
\text { research topics and the supportive method in } \\
\text { which they are conducted. } \\
\text { Strategies to minimise boundary confusion } \\
\text { include clearly outlining the roles of the } \\
\text { researcher prior to interviews, having multiple } \\
\text { researchers attend interviews, having transcripts } \\
\text { read by other researchers to monitor boundary } \\
\text { maintenance, and ongoing debriefing sessions } \\
\text { for researchers. }\end{array}$ & $\begin{array}{l}\text { Being aware of the potential for boundary } \\
\text { confusion may be particularly important when } \\
\text { conducting qualitative research with families } \\
\text { living with ASD. First, children and individuals } \\
\text { with ASD may find it difficult to understand the } \\
\text { unique role of a researcher, particularly when } \\
\text { interviews are conducted with a supportive nature } \\
\text { and within the family home. Second, the } \\
\text { emotionally laden topics that are often inherent to } \\
\text { this research area may lead participants to become } \\
\text { confused about the researchers' role. Additionally, } \\
\text { researchers themselves may become confused } \\
\text { about their role, particularly if they have a } \\
\text { personal connection to the research topic and/or } \\
\text { professional roles other than a researcher (e.g., } \\
\text { counsellor, support worker, teacher, etc.). }\end{array}$ \\
\hline 5e. & $\begin{array}{l}\text { Researcher } \\
\text { health: } \\
\text { Developing and } \\
\text { maintaining } \\
\text { healthy } \\
\text { boundaries }\end{array}$ & $\begin{array}{l}\text { Consider the } \\
\text { differences in } \\
\text { power in the roles } \\
\text { of researchers and } \\
\text { participants. }\end{array}$ & $\begin{array}{l}\text { In most research, there is a power difference } \\
\text { between researcher and participant due to the } \\
\text { researcher's in-depth knowledge of the particular } \\
\text { research area. However, in qualitative research it } \\
\text { is acknowledged, and even embraced, that } \\
\text { participants are the expert in their own right as it } \\
\text { is their personal experiences and opinions that } \\
\text { are under investigation (Brinkmann, 2007). }\end{array}$ & $\begin{array}{l}\text { It may be helpful to acknowledge the participants' } \\
\text { unique role as "expert" regarding being an } \\
\text { individual/family member living with ASD. Such } \\
\text { acknowledgement may facilitate participants' } \\
\text { sense of mastery and highlight the value of } \\
\text { sharing their experiences in the research. }\end{array}$ \\
\hline
\end{tabular}




\section{FIGURE CAPTION.}

Figure 1. Stages of qualitative research discussed in paper. 